\title{
DOS LÁBIOS QUE NARRAM AO OLHO INVISÍVEL: ESTRATÉGIAS NARRATIVAS EM CAPITU
}

Saulo Lopes de Sousa*

https://orcid.org/0000-0001-6290-5954

Gilberto Freire de Santana**

(iD) https://orcid.org/0000-0002-3018-3018

Como citar este artigo: SOUSA, S. L. de; SANTANA, G. F. de. Dos lábios que narram ao olho invisivel: estratégias narrativas em Capitu. Todas as Letras - Revista de Lingua e Literatura, São Paulo, v. 22, n. 3, p. 1-18, set./dez. 2020. DOI 10.5935/ 1980-6914/eLETDO2013573

Submissão: julho de 2020. Aceite: setembro de 2020.

Resumo: Este artigo investiga as estratégias próprias do audiovisual a fim de se perceber como se dá a narração na microssérie Capitu (2008), dirigida por Luiz Fernando Carvalho. Trazem-se à baila contribuições da narratologia cinematográfica, a respeito da existência de uma instância narradora no cinema, no rastreio de expedientes enunciativos encarregados da atividade narrativa na obra carvalhiana. Destaca-se a manipulação da câmera como um dos traços narrativos que, articulado e sintonizado com outros recursos, colabora para a própria especificidade da narração na microssérie.

Palavras-chave: Adaptação. Estética audiovisual. Ficção seriada. Instância narrativa. Microssérie Capitu. 
O narrador é o homem que poderia deixar a luz tênue de sua narração consumir completamente a mecha de sua vida (BENJAMIN, 1987, p. 221).

\section{Obliguidades NARRATIVAS}

N arrar sempre teve função de destaque no processo que arquiteta a ficção, pois a partir desse exercício a teia narrativa se fia. No trânsito da literatura, setor verbal, para o cinema e a televisão, campos audiovisuais, a questão do narrador se abre ao debate, sobretudo quando se põem em revelo os incursos da adaptação.

A discussão em torno da função narrativa, isto é, de uma instância narradora responsável pela transmissão de um relato, é pertinente também ao setor audiovisual $^{1}$, cuja experiência se realiza, sobretudo, a partir da matéria ficcional. Tomemos, então, a cinematografia como fito para discussão. No cinema, uma história é "contada" por meio da manipulação de imagens e sons postos em sequência ${ }^{2}$; a isso se soma a percepção desse mesmo ato narrativo por parte do espectador mediante exercícios de escuta e de visão do conteúdo transmitido no écrã. Em resumo: o cinema incita uma percepção audiovisual.

Então, faz-se imperioso que, neste momento, nos perguntemos: como se pensar a função narrativa cinematográfica? O que ou quem "narra" no cinema? Existe uma "presença" no filme que nos conta a história? Questões como essas são feitas, sobretudo, como tentativas de se abrir espaço ao debate mais específico sobre a vasta extensão de obras filmicas e audiovisuais que, não raro, estão modulando a natureza de seus discursos para outros patamares.

Por esse motivo, garimpamos subsídios no referencial teórico da narratologia cinematográfica no esforço de fomentar a discussão em torno da instância enunciativa na microssérie carvalhiana. A teoria do cinema se faz necessária em virtude da restrita bibliografia centrada especificamente na questão da instância narradora em narrativas televisuais, sendo-nos conveniente, por esse motivo, os achados conceituais dos estudos cinematográficos. Assim posto, buscamos levantar questões referentes à "presença" de uma instância narradora no cinema, discutindo os mecanismos de enunciação cinematográfica para, na medida do possivel, pensá-los na microssérie.

\section{Olhar além do Ver: “NARRANDo” A IMAGEM-SOM}

Alguns teóricos do cinema têm se empenhado em mapear os caminhos de investigação do narrador cinematográfico, ou da instância narradora no cinema. Vemos que essa categoria narrativa também possui um leque diversificado de estudos empreendidos por teóricos da literatura. Com nomenclaturas específicas, tais estudiosos ${ }^{3}$ buscam sondar os modos basilares de constituição e atuação do narrador na configuração ficcional.

1 Compreendemos o audiovisual como aquelas "obras que mobilizam a um só tempo, imagem e som, seus meios de produção e as indústrias ou artesanatos que as produzem" (AUMONT; MARIE, 2003, p. 25). Desse conjunto participam os filmes, a televisão e as mídias audiovisuais (clipes, vídeos etc.).

2 Operação que corresponde à montagem, entendida por Betton (1987) como técnica responsável por contar uma ação mediante a junção de diversos fragmentos de realidade, no caso, os planos, cuja sequencialização se presta a constituir uma totalidade significativa. Para a narratologia do cinema, é na montagem que se dá a concretude do processo cinematográfico, pois aí a narrativa se constrói.

3 À guisa de notação, podemos citar Pouillon (O tempo no romance, 1974), Stanzel (Formas típicas do romance, 1971), Todorov (As categorias da narrativa literária, 2011) e Tacca (As vozes do romance, 1983). 
Não raro se tenha em vista a existência do narrador, os regimes atuais de produção ficcional instauraram vias de problematização de sua natureza e atividade. Convêm, para esse exame, as reflexões de Benjamin (1987) sobre a questão do apagamento do narrador primitivo $\left(a_{e} \operatorname{dos}^{4}\right)$, herança da épica clássica, quase em vias de extinção, para o surgimento de posturas mais difusas de enunciação narrativa. Quando outrora no romance tradicional, a figura narrativa, enquanto representação de uma voz diegética, dava a conhecer o conteúdo narrativo, mantinha-se certa distância estética. Advinda a sensação de impotência diante do fazer narrativo, sua visão dos fatos torna-se limitada, não mais confiável, apresenta um ponto de vista vulnerável, a ponto de Adorno (2003) decretar a morte do narrador.

Adorno, ao verificar a posição do narrador no romance contemporâneo, corrobora a constatação de que o narrador enquanto "dono" dos desígnios do relato sofre profundos abalos em virtude da falência verificada na arte do narrar. Tal tendência determina o desafio tanto para a Teoria da Literatura quanto para a Narratologia de angariar novas alternativas de se compreender o fenômeno flutuante do ato narrativo. A discussão sobre o narrador e sua investidura abarca também a cinematografia.

É inegável que as análises filmicas sofram forte influência dos estudos literários, com base, principalmente, nos contributos teóricos de Genette (1978). Consoante a isso, faz-se compreender que, até atingir a maturação necessária ao vislumbre de sua especificidade, a narrativa cinematográfica foi pensada pelo viés da categorização literária, e até mesmo por analogias com a Linguística, quando, por exemplo, algumas abordagens críticas empregam o termo "enunciação". Entretanto, é imprescindivel notar que a lógica e os esquemas estruturais da literatura não se aplicam plenamente à dinâmica do cinema, razão que alicerça, por assim dizer, o apartamento entre as duas zonas ficcionais.

As intersecções entre literatura e cinema com relação à instância do narrador são claramente anunciadas por Gaudreault e Jost (cf. GAUDREAULT; JOST, 2009), ao recuperar o preceito da focalização narrativa ${ }^{5}$ inaugurado por Genette. Como a focalização congrega em si os aspectos de visualidade e de conhecimento, Jost se põe convicto da inescapável desligadura entre o saber e o ver, considerando que "o filme sonoro pode mostrar o que o personagem vê e dizer o que ele está pensando" (GAUDREAULT; JOST, 2009, p. 167), ou então que a câmera pode narrar aquilo que o narrador não consegue apreender. Nessa abordagem, a focalização conserva o ponto de vista cognitivo, ao passo que, para o ponto de vista visual, o teórico sublinha o designativo ocularização, concernente àquilo que mostra a câmera e o que o personagem parece ver.

Jost, diante dessa conjectura, fixa como ponto definidor da ocularização o "olho" agenciador da cena, que pode pertencer à câmera ou à personagem:

Isso quer dizer que existem três possíveis atitudes em relação à imagem cinematográfica: ou é considerada como vista por um olho, o que faz com que se remeta a um personagem; ou o estatuto e a posição da câmera vencem e passamos a

4 Oriundo do verbo grego "aidô", que significa cantar, o aedos era o antigo recitador de poesias épicas, sempre acompanhado pelo som de um instrumento musical.

5 Designada também de ponto de vista ou foco narrativo, "a focalização pode ser definida como a representação narrativa a partir de um determinado campo de consciência ou perspectiva" (BULHÕES, 2009, p. 51), quer seja de um personagem inserido na trama, quer seja do narrador posicionado externamente a ela. 
atribuí-los a uma instância externa ao mundo representado, grande imagista de qualquer tipo; ou tentamos apagar até mesmo a existência desse eixo: é a famosa ilusão de transparência (GAUDREAULT; JOST, 2009, p. 1669).

Partindo desse pressuposto, o autor elenca duas opções praticáveis: a ocularização pode ser interna, quando se impõe uma conexão imediata entre a imagem mostrada pela câmera e a perspectiva da personagem, ou zero, definida pela objetividade da câmera, sem a ótica subjetiva da personagem, criando, assim, a impressão de que a narrativa se narra a si mesma, dispensando a intervenção da figura do narrador ${ }^{6}$.

Apesar de fincadas sob forte fundamento teórico-metodológico, as noções apreciadas por Jost devem ser analisadas com certa parcimônia. Conforme nos certifica Silva (2011), as circunstâncias de focalização interna e externa, na narrativa cinematográfica, transportam seu acervo cognitivo para além do ponto de vista da personagem ou da objetiva da câmera. Tendo em vista a multiplicidade de elementos participantes da sétima arte, a produção e a transmissão de um sentido ao espectador não se dão apenas pela esfera bilateral do eixo personagem-câmera, mas perpassam outros diversos códigos e mecanismos próprios da construção no cinema.

A propósito da ocularização, igualmente, podemos levantar alguns aspectos deficientes:

No caso da ocularização interna, por exemplo, uma situação impossível na literatura se faz notar. Muito embora determinado personagem possa estar em cena e em função da sua voz off ainda sugerir que é a responsável pelo conteúdo audiovisualizado, ele ainda permanece sendo visto a partir de uma perspectiva exterior, e não sob um ponto de vista interno. Nesta situação, é o olho externo, imediatamente relacionado com fazer da câmera, bem como outros dispositivos que possibilitam a audiovisualização daquilo que o personagem relata (SILVA, 2011, p. 123).

Inegavelmente, essa situação pulula de forma dominante na minissérie Capitu, pois em diversos momentos o personagem Dom Casmurro coabita o mesmo espaço-tempo de suas memórias, nas quais se audiovisualizam as outras versões de sua persona (Bentinho e Bento Santiago). Quando no serviço de narrar verbalmente as próprias reminiscências, Dom Casmurro é sujeito da enunciação; quando é mostrado na cena, passa a ser sujeito do enunciado. Dado a ver, Dom Casmurro, além de ser voz, é também presença, tornando-se matéria da leitura pelo olho da câmera. A partir dessas considerações, é patente inferirmos que as aproximações entre as categorias literárias e o constructo do cinema não garantem plena correspondência.

Alinhado às abordagens metodológicas intentadas por Jost, Gaudreault (cf. GAUDREAULT; JOST, 2009, p. 58-69) sai em defesa da enunciação ${ }^{7}$ no território do cinema, cujo substrato reporta, instantaneamente, ao fenômeno da subjetivação da linguagem postulada pelo linguista Émile Benveniste. Por esse motivo,

6 Essa dinâmica é comumente rompida quando, em determinados momentos, a ocularização zero passa a ser interna, contudo sem a sensação da presença de personagem.

7 Fiorin (2006) dirá que a enunciação é o local de inscrição do sujeito e ponto de referência das relações espaçotemporais, considerando que tempo e espaço estão sob tutela do eu, que a partir deles efetiva sua enunciação. Por isso, a enunciação pressupõe a existência de sujeitos produtores de enunciado. 
o autor acredita haver na narrativa filmica um narrador fundamental que a comunica, muito embora perceba que essa instância, longe de transparecer feições antropomórficas, se comporta como um sistema múltiplo de operações discursivas, destinado a manipular e agenciar as diversas matérias de expressão filmica, ditando, dessa forma, as coordenadas de informações narrativas entregues ao espectador.

Nesse posicionamento, meganarrador ou grand imagier é o termo proposto por Gaudreault para ilustrar a grande figura produtora da narrativa audiovisual, que se doa de forma oculta e quase imperceptivel na superficie filmica. Originalmente, o termo havia sido elaborado por Albert Laffay e concentra a ideia de "foco virtual da enunciação filmica [...], uma espécie de grão-mestre das imagens" (AUMONT; MARIE, 2003, p. 200).

Força moduladora da narratividade no seu nivel superior, o meganarrador determina, também, as fatias subordinadas ao seu poder central, espécies de camadas discursivas subsequentes ao plano da meganarrativa, que o autor designa de mostração e narração. Enquanto primeiro nivel narrativo, a mostração articula a encenação (mise-en-scène) e o enquadramento no interior do fotograma, e o agrupamento contínuo de fotogramas para a fabricação dos planos. O trabalho da mostração é, dessa forma, pôr em cena, enquadrar. Ao nível da mostração é acrescentado o segundo, a narração, no qual se efetua a reunião de diferentes planos dispostos numa sequência temporal, processo distintivo da montagem. Também compõe esse panorama teórico a premissa de que o ato de narrar, de modo eventual, é delegado a narradores segundos ou subnarradores atorializa$\operatorname{dos}^{8}$, quando estes narram verbalmente no cinema.

Concordando com a existência da enunciação cinematográfica, Gardies (2006) concebe a instância narradora como responsável pelo doar da narrativa no cinema, pois além de sua função atrelada ao contar, o narrador também produz o enunciado filmico e o transmite ao espectador. O crítico, por seu turno, sugere o termo polarização, compreendido como o intercâmbio de informações gerido pela tríade enunciador, personagem e espectador. É exatamente no espectador que incide o parâmetro investigativo desse sistema, dado que o interesse maior consiste em rastrear as questões do saber mediante a efetiva participação do espectador no processo filmico.

Em virtude desse quadro, Gardies (2006) elenca três situações-tipo: polarização-personagem, quando o espectador iguala seu saber ao da personagem; polarização-espectador, em que o espectador ocupa uma posição de onisciência, como se as informações do filme lhe angariassem a impressão de um saber supremo; e polarização-enunciador, na qual o espectador se percebe dono de um saber raso, sentindo-se na iminência de que o enunciador lhe revelará alguma informação sob sigilo.

Nitidamente, vemos que Gardies se empenha na sondagem das estratégias pelas quais o leitor-espectador participa do desenrolar da história, o que nos faz intuir uma atenção especial dada à recepção fillmica. Sendo assim, o autor concentra seu olhar nos "processos pelos quais cada filme gere o acesso ao saber diegético" (GARDIES, 2006, p. 109), ou seja, de que meios se vale o espectador na construção de seu saber do mundo diegético.

8 O termo atorializar, aqui, é um neologismo encontrado para representar a audiovisualização do narrador. 
Para a enunciação cinematográfica, "o texto filmico se desenha, se enraíza e se volta sobre si mesmo" (AUMONT; MARIE, 2003, p. 99). Dito isso, todos os artificios de que se vale a estrutura cinematográfica descortinam a feitura do filme e o fazem dobrar-se sobre si mesmo, revelando as instâncias que o organizam. São esses lastros enunciativos que, dados a conhecer ao espectador, abalam o contrato ficcional, pois uma vez manifestados os dispositivos, desfaz-se a noção de verossimilhança e o espectador, de imediato, tem a constatação de que o conteúdo filmico é uma "verdade" construída. Tal perspectiva muito se avizinha da ideia de narrador contemporâneo, pensada por Adorno, pois a narrativa exibe os artefatos da sua própria construção, revelando ao leitor que ele está diante de uma ficção.

Partidário das convicções teóricas de Gardies e Casetti, Metz (1993) desacredita na enunciação cinematográfica de cunho antropomórfico tal como se manifesta no enunciado de natureza verbal. Consoante seu parecer, o texto escrito (literário) deixa à mostra a impressão de uma presença enunciativa devido às marcas dêiticas, fato dificilmente observável no enunciado filmico. De posse desse argumento, Metz adverte que o enunciador (ou narrador) no cinema não pode ser confundido com um ser empírico, antropomorfizado, pois a função narrativa está voltada para a força que articula e agencia as informações edificadas no domínio filmico.

Diferentemente do sistema verbal, cujos códigos dêiticos informam acerca dos atores envolvidos no intercâmbio enunciativo, bem como das condições espaçotemporais de sua produção, no texto filmico, essa alçada é impraticável, pois não há particularização de suas instâncias produtivas; no máximo, o filme só consegue aludir a representações genéricas ou parciais. Em todo o caso, Metz nos fia que a enunciação no cinema pode ser pensada como um procedimento que revela a própria feitura do produto audivisual, seu fazer específico que o organiza como tal. Então, o enunciado filmico tende, necessariamente, a ser metadiscursivo e compreendido como

[...] um aparato enunciativo que não é necessariamente dêitico (e, portanto, antropomórfico), nem pessoal (como os pronomes que assim se denominam), e que imita de perto esse ou aquele dispositivo linguístico, uma vez que a inspiração linguística funciona melhor de longe (METZ, 1993, p. 60, tradução nossa) ${ }^{9}$.

Fugindo, pois, da alçada antropomórfica e dêitica que espreita a enunciação, Metz opta pela mudança de emprego das expressões "enunciador" e "enunciatário", cujas desinências muito claramente habitam o terreno linguístico e referenciam, suspeitosamente, a atmosfera antropomórfica, para as nomenclaturas "fonte ou foco da enunciação" e "alvo ou destino da enunciação", tidas por ele como termos mais intransitivos.

Imbuído de tornar mais visivel sua análise, o crítico detecta que a enunciação é perceptivel não por unidades dêiticas, mas sim por construções reflexivas, que assinalam a ocasião em que "[...] o filme fala de si mesmo, do cinema ou da posição do espectador [...]" (METZ, 1993, p. 60, tradução nossa) ${ }^{10}$. Funciona como

\footnotetext{
9 No original: "[...] um aparato enunciativo que no sea necesariamente deíctico (y por tanto, antropomórfico), ni personal (como los pronombres que se los llama, así), y que imite de muy cerca tal o cual dispositivo linguístico, puesto que la inspiración linguistica se logra mejor de lejos".

10 No original: "[...] la película nos habla de ella misma, o del cine, o de la posición del espectador [...]".
} 
uma espécie de "dobra", como se o enunciado se curvasse sobre si mesmo, pondo à mostra seus segredos, funcionamentos e condições de produção. Ao mesmo tempo, as construções reflexivas, por serem metafilmicas ou metadiscursivas ${ }^{11}$, sinalizam ao espectador que ele presencia, ante seus olhos, um produto de ficção cinematográfica. A critério de exemplificação, Metz destaca como figuras de reflexividade da enunciação o filme no filme, direção off, direção in, imagem subjetiva, campo-contra-campo, flashback, dentre outras formas.

Machado, a propósito da enunciação no cinema, circunscreve a dinâmica diegética do filme sob o prisma de um olhar ou um sujeito cinematográfico, princípio articulador imbuído de determinar o ângulo de visão, as distâncias e os enfoques para com aquilo que se vê e se ouve. Esse mesmo olhar, que oferta a primeira visão, é automaticamente assimilado pelo espectador como seu próprio olhar. Por outro lado, trata-se de um olhar de maior envergadura, cujas demarcação e localização no corpo da narrativa são bastante dificeis, dada sua natureza imperceptivel. Dessa forma, o autor comunica que esse sujeito enunciador na tela se filia ao fazer da câmera:

Encarnação desse observador onividente, a câmera procura sempre dar a melhor imagem possível do que está sendo acontecendo em cena, com as ênfases necessárias à inteligibilidade da história. Ela tanto pode ver uma ação de modo distanciado, de um ponto longínquo e superior em relação à cena, como também e imediatamente saltar para bem perto de uma personagem para observar uma sutil hesitação em sua face (MACHADO, 2007, p. 26).

Há de se pensar, portanto, que essa instância narradora possui como diferencial a capacidade de transmitir as informações sonoro-imagéticas sem necessitar descrevê-las, isto é, "o filme é muito diferente do romance pelo fato de poder mostrar ações sem dizê-las" (GAUDREAULT; JOST, 2009, p. 57). Se no romance é o narrador que, com sua voz, comanda o andamento dos lances narrativos, segundo sua ótica de observação, no cinema, a história é mostrada pelo "olho" que agencia os planos, os enquadramentos, as cenas: "O cinema - o cinema narrativo, é claro, esforça-se, portanto, para esboçar uma sintese do sujeito narrador (aquele que 'conta') com o sujeito enunciador da imagem (aquele que vê e, por extensão, ouve)” (MACHADO, 2007, p. 18).

O que esse "olho" específico possibilita vai muito além das capacidades visuais do olho humano, pois a câmera cinematográfica se mostra com destreza transcendente de invadir os espaços e as coisas como um observador invisivel, onividente e totalizante, arrancando dos fatos mais profundos aos mais ocultos, a sua visualidade mais completa. Arlindo chama de ubiquidade, portanto, a função enunciativa da câmera, essa força demiurga que a instância narradora expõe de rastrear opticamente de forma autônoma e irreprimivel, como uma espécie de voyeurismo supremo, que tudo perscruta, tudo dá a ver. Por esse motivo, Arlindo afirma que o termo "narrador", em se tratando de sujeito enunciador no cinema, deve ser tomado numa acepção metafórica, ainda que de cunho antropomórfico, por se tratar de uma função simbólica exercida pelo texto cinematográfico, e não por um indivíduo real como se tenciona supor (cf. MACHADO, 2007, p. 19).

11 Termos empregados por Metz (1993). 
Para além da teoria clássica, Bordwell (1996) reformula a concepção de narrador como orquestrador e fonte do relato. Para esse estudioso, o processo narrativo, em eventuais momentos, sugere ao espectador a possibilidade de construir um narrador. Nessa circunstância, o narrador resulta de especificidades dos princípios de organização no filme. Assim posto, Bordwell (1996, p. 62, tradução nossa) se convence de que "este tipo de narrador não cria a narração; a narração apelando a normas históricas de visualização, cria o narrador"12. Então, é nos procedimentos de construção cinematográfica que se pode captar uma possivel instância narradora.

À luz dessas explanações, podemos inferir, de forma patente, que as linhas teóricas, na inspeção da problemática do narrador na ficção audiovisual (cinema, televisão, games, animações etc.), atestam a existência da instância narradora destituída de atributos antropomórficos, como também percebem o ato enunciativo como um fundamento nuclear e agenciador de todos os expedientes que, no cinema, numa teledramaturgia, nos jogos virtuais ou em qualquer outra ficcção midiática, "narram" a imagem-som.

A proposta deste estudo, por conseguinte, é tentar indicar qual a instância narradora dentro da adaptação do romance Dom Casmurro para a TV. Sendo assim, tomaremos a enunciação como arcabouço constituído por métodos e mecanismos vinculados às práticas de mostração e escuta, sejam elas cinematográficas ou não. Além disso, nosso pensamento conceberá a instância narradora "desantropomorfizada", identificada e encarnada na atividade da câmera, mas também como agrupamento de diversos dispositivos capazes de particularizar a narração audiovisual, evidenciando contornos e paradigmas diferentes daqueles detectados no narrar literário.

\section{JANELA DE FLÂNEUR: OLHO-CÂMERA ENUNCIATIVO}

O olhar nômade de Dom Casmurro lançado às memórias revisitadas é, sem dúvida, o tênue fio de Ariadne que alicerça a condução de Capitu. Todo o universo representado na microssérie segue os passos hesitantes desse sujeito casmurro que espreita o passado, sempre escondido atrás das cortinas, às vezes mais próximo dos acontecimentos e das personagens. Entretanto, podemos constatar que a linguagem televisual, tributária das articulações técnicas provenientes da arte cinematográfica, também aciona diversos recursos para colaborar na narração da história, estampando nas cenas possiveis sentidos e percepções.

Dada a premissa de que, na doação da imagem-som, a função enunciativa perpassa, por assim dizer, uma multiplicidade de artificios aptos à comunicação narrativa, sublinhamos como importante contributo desse empenho a manipulação da câmera como marca correlativa do sujeito que olha. O "olho" privado da câmera executa, portanto, uma espécie de

[...] clivagem da instância "narradora", repartindo-a em sujeito visível (o "contador" da história que aparece no começo, no meio e nos reflexos do espelho) $e$ sujeito invisível (o grande voyeur que doa a imagem e sob a mediação do qual entramos na trama (MACHADO, 2007, p. 37).

\footnotetext{
12 No original: "este tipo de narrador no crea la narración; la narración apelando a normas históricas de visionado, crea al narrador".
} 
Seguindo essa trilha teórica, depreendemos que o ponto de vista da personagem Dom Casmurro, a partir da qual despontam os fatos da diegese e o próprio irromper da narração, é também subvertido e assimilado pela perspectiva ocular da câmera, revelada no seu exercício de operar cortes, manobrar ângulos/tomadas e objetivar personagens no enquadramento. Por isso mesmo é que seu manuseio se instala na organização ficcional da microssérie como mais uma característica da instância narradora, ao entrever a existência de uma possível "[...] dualidade do olhar que faz a ambivalência do sujeito" (MACHADO, 2007, p. 59).

Diante do exposto, a experimentação da câmera efetuada em Capitu funciona como uma bússola e guia o espectador num nítido flaunerismo que adentra e perscruta todos os espaços, fixando uma visão mais penetrante da imagem. De tal modo, quando a voz-corpo silencia ante a incomunicabilidade de um dizer, resta-lhe doar a "palavra ao olhar lançado ao outro [...] para que se possa narrar o que a palavra não diz" (SANTIAGO, 2002, p. 56). Simbolicamente, o rito de recobrir com palavras esse olhar é expresso nas cenas em que a câmera focaliza a escritura do romance (Figura 1), iluminando, com o reflexo de sua lente, a pena a grafar as letras no papel.

Figura 1 - Escrituras do olhar
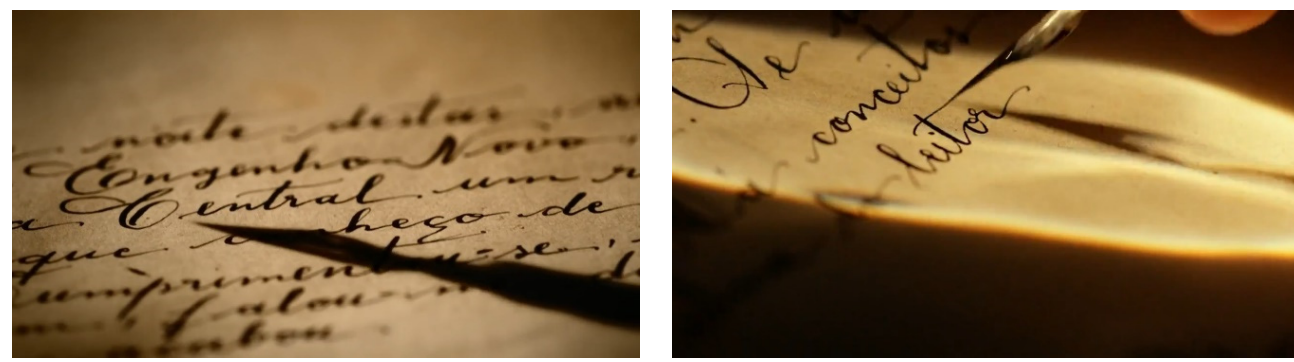

Fonte: DVD Microssérie Capitu (2008).

O primeiro distintivo que se faz notar é a insinuação da câmera como um "olho" fragmentado em diferentes pontos de vista, associado, sobretudo, à visão de Dom Casmurro. Como a narrativa é centrada no olhar depositado por essa personagem, majoritariamente, a narração seguirá sua perspectiva de visão, considerando o fato de que, estando ele alocado no interior de suas memórias reconstituídas, o que é visto/ouvido na história provém de sua subjetividade. Em inúmeras passagens da microssérie explicita-se a correspondência entre o ponto de vista da câmera e a personagem Dom Casmurro como instância que vê, mediante as múltiplas figurativizações da câmera subjetiva ${ }^{13}$. Uma delas é a representação do foco ocular de uma pequena luneta, pela qual Dom Casmurro observa sua mãe no leito de doença, sob os cuidados de Capitu. Em outro momento, quando do retorno de Bentinho do seminário, a personagem é mostrada segurando um tipo de lente emoldurada à frente do rosto, e, em seguida, a câmera passa a focalizar as cenas circunscritas nessa moldura (Figura 2).

13 Também entendida como plano subjetivo, corresponde à assimilação de um enquadramento à visão de uma personagem da diegese (cf. AUMONT; MARIE, 2003, p. 279). 

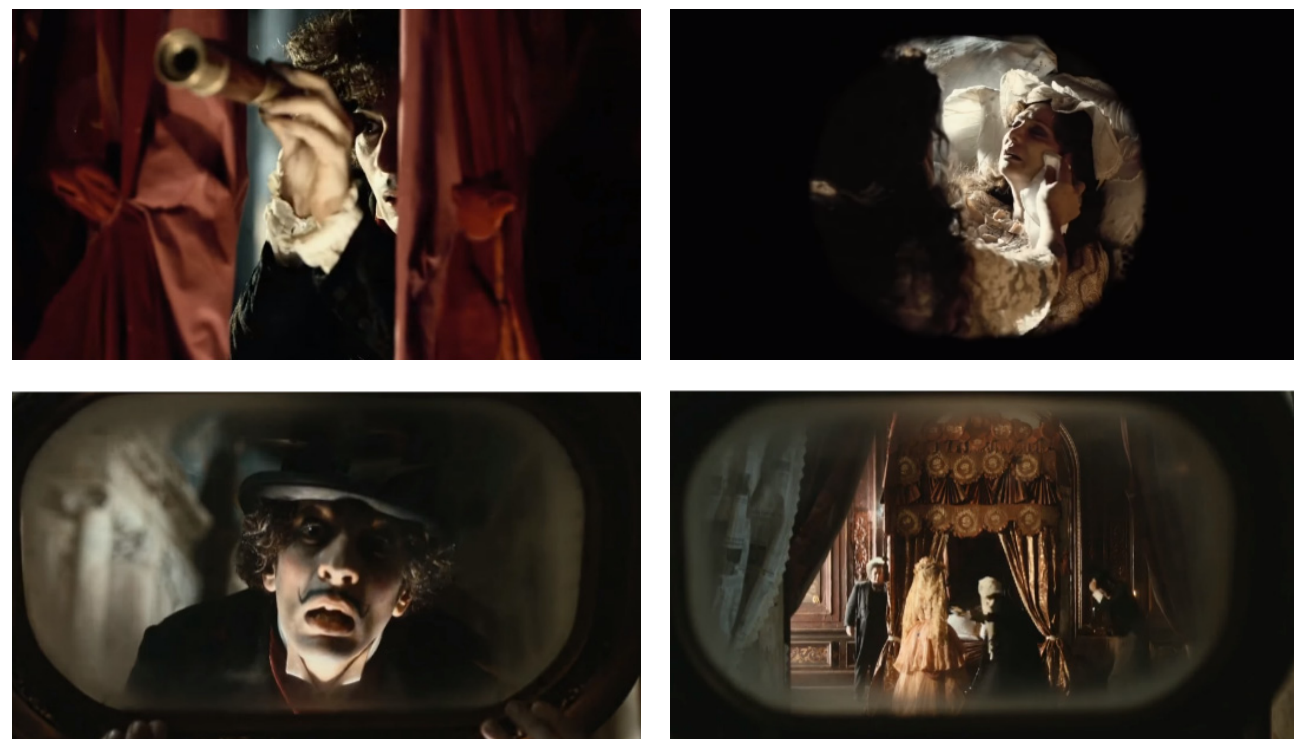

Fonte: DVD Microssérie Capitu (2008).

Enquanto objetos de composição cênica, a luneta e a moldura ilustram, exemplarmente, a qualidade flaneurística ${ }^{14}$ da orientação da câmera, pois mimetizam a visão de um verdadeiro andarilho, indivíduo que observa en passant ${ }^{15}$ os eventos e as pessoas ao seu redor. É justamente essa a sina de Dom Casmurro: estar fadado a vaguear pelas veredas de suas memórias, na tentativa de restituir à mente as porções reminiscentes de sua vida passada e delas extrair respostas ao seu conturbado dilema. Isso também faz com que o espectador seja convocado a ser testemunha ocular de tal intento, porque a mesma visão obtida pelo personagem é compartilhada com quem audiovisualiza a cena. É desejo do protagonista, por esse efeito, que vejamos a história a partir de seus olhos, que adentremos a trama tão somente orientados por sua ótica e seu discurso, como se a única "verdade" confiável fosse a dele mesmo. Desse modo, como que privado de visão própria, o espectador é levado pela mão a seguir os mesmos passos do solitário flâneur, na unilateralidade do seu ver, pois a lente, posta aos nossos olhos, objetiva que possamos ver os fatos com mais nitidez, mas esquece a personagem que sua lente já veio embaçada pela ação do tempo e do ciúme.

Pela mesma estratégia, a perspectiva da câmera assume o ponto de vista de outros personagens da diegese. Citamos, por exemplo, a rápida aparição de duas senhoras à janela (Figura 3), uma delas a usar binóculo, ambas representando a agitação da vizinhança com a chegada do Imperador à casa de D. Glória. Assim, o rei é focalizado numa moldura binocular.

14 Referimo-nos ao conceito de flâneur, elaborado por Baudelaire (2006), como figuração do sujeito observador da vida urbana moderna. Dadas as transformações ocorridas na Europa de meados do século XIX, Baudelaire lança mão do termo para analisar os padrões estéticos da insurgente sociedade parisiense, com vistas à sua adequação aos processos dinâmicos do novo contexto histórico. A posteriori, Benjamin (2000) retoma a ideia baudelairiana do flâneur em seus escritos, porém alargando sua condição indispensável de testemunha ocular da vida na cidade. Assim, Benjamin deposita na figura do flâneur a carga de alienação oriunda dos efeitos do capitalismo de consumo.

15 Expressão do francês que, dentre outros sentidos, quer dizer "de passagem". 
Figura 3 - Flaneurismo do olhar do espectador
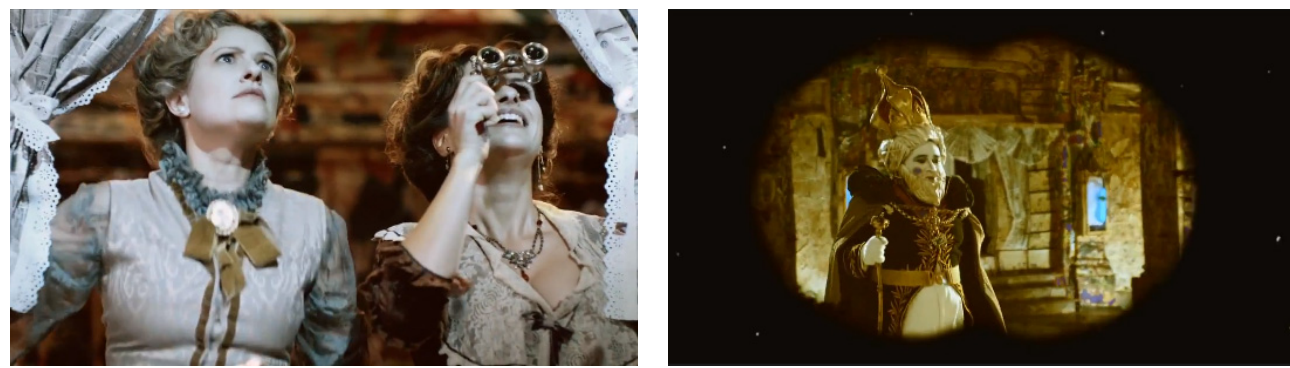

Fonte: DVD Microssérie Capitu (2008).

De modo distinto, a visão que a senhora obtém, materializada na imagem binocular de vossa majestade, não é uma visão forjada pelo olhar de Dom Casmurro, mas pela perspectiva que a personagem estabelece ao observar o acontecimento. O flaneurismo, aqui, permanece, mas agora sob nova concepção: o espectador, aquele que assiste aos episódios que se desenvolvem na narrativa, pode decidir que ponto de vista adotar, ou mesmo rejeitar aquele que lhe é apresentado como único válido de confiança. Dado que Dom Casmurro oferece, de bom grado, ao seus leitores-observadores uma "lente casmurra" capaz de amplificar a ótica das situações a seu bel-prazer, estes se veem livres para escolher de qual ângulo olhar, qual ponto de vista adotar, uma vez que também flanam pelas vielas de suas lembranças. Como percebemos, diferentes relações de sentido são possibilitadas pela exploração do mesmo recurso enunciativo, princípio que potencializa os dizeres da representação ficcional. Consequentemente, múltiplas são as leituras que daí se podem depreender.

Noutras ocasiões, é o olhar de Bentinho que figura na imagem captada pela câmera, na maioria das vezes, espreitando de longe outros personagens, pela fresta de cortinas. Ou quando da visita a Capitu, em que ambos se sentam no canapé e, enquanto a menina olha para o chão buscando a própria interioridade e refletindo sobre a decisão de D. Glória de enviar o filho ao seminário, o menino captura, de fato, a imagem que vê do chão (Figura 4), descrita por Dom Casmurro: "o roído das fendas, duas moscas andando e um pé de cadeira lascado" (ASSIS, 1997, p. 91).

Figura 4 - Metáforas do olhar de Bentinho
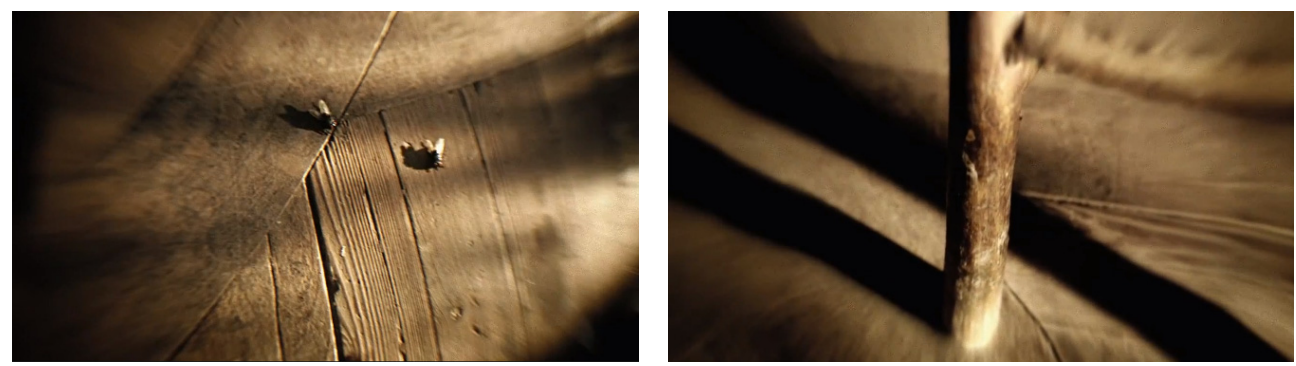

Fonte: DVD Microssérie Capitu (2008).

Nessa ocorrência, o poder simbólico da câmera entra em ação, alia o seu dizer à palavra proferida pelo personagem e confere uma significação poética à 
cena. Sabemos, pela mostração da sequência, que os personagens se encontram assentados no canapé da sala. A imagem de Capitu, sôfrega e abatida, ao olhar o chão na tentativa de refletir o discurso da mãe de Bentinho, revela seu abatimento tanto físico como psicológico, diante da iminência da partida de Bentinho rumo ao sacerdócio. Já a imagem captada por Bentinho, que fitava deveras o chão, como confessada por ele, visualiza os elementos componentes de sua visão: sob cor acastanhada, mas de tonalidade esmaecida, temos no enquadramento duas moscas que passeiam, ermas, pelo chão de madeira, além da focalização do pé de cadeira em lascas. As duas visualizações, nessa situação específica, articulam-se metaforicamente ao texto, no sentido de materializarem, de modo plástico, a atmosfera de desabrigo e aflição em que se depara o casal de jovens. Dessa forma, a visão das moscas, insetos que "simbolizam uma busca incessante" (CHEVALIER; GHEERBRANT, 2015, p. 623, grifo do autor), alegoriza a ânsia de Capitu por obter a resolução urgente de suas indagações, para que a esperança do vínculo amoroso com Bentinho não se rompesse. Igualmente, os seres simbolizam a mesma emergência de Bentinho em atenuar o abatimento da donzela. Os dois, portanto, se encontram desnorteados, assentados fisicamente num ponto de apoio - o canapé -, entretanto à deriva no chão de madeira desgastada, tal como será a relação de ambos, caso a separação prometida por D. Glória se cumpra: um amor envelhecido, vaticinado à finitude.

Esse estreito vínculo entre o que diz a palavra e o que mostra a imagem é mais um indicativo que comprova a capacidade do olhar da câmera de acrescentar uma informação à história, insuflar no espectador sensações e dizeres outros que o discurso, sozinho, não consegue iluminar. Inegavelmente, o trabalho colaborativo firmado pelos dois dispositivos - voz-corpo e olho-câmera - valida a prerrogativa de que a instância enunciativa na teleficção não se reveste de couraça antropomórfica, pois os diversos mecanismos acionados na construção da linguagem audiovisual "[...] podem ser apontados como marcas, pistas da enunciação dado que, todos eles, com a especificidade que lhes é própria, buscam consolidar uma narrativa, permitindo que a mesma tenha sua evolução garantida" (SILVA, 2011, p. 155).

Outro ponto contemplado pelo artifício da câmera consiste na transmutação do seu olhar numa instância vidente, isto é, numa "presença invisivel, observadora e não antropomórfica, cujo olhar embora às vezes se identifique com a perspectiva dos personagens, em determinadas ocasiões, também tem sua autonomia bem marcada" (SILVA, 2011, p. 135). Não se confundiria, portanto, com o olhar do espectador projetado na objetiva da câmera, tampouco com a visão subjetiva de outras personagens, mas sinaliza a existência de um terceiro olhar, flâneur por excelência, que dá a ver a cena conforme a independência de suas coordenadas de atuação, bem como os propósitos enunciativos:

Encarnação desse observador onividente, a câmera procura sempre dar a melhor imagem possível do que está acontecendo em cena, com as ênfases necessárias para a inteligibilidade da história. Ela tanto pode ver uma ação de modo distanciado, de um ponto longínquo e superior em relação à cena, como também e imediatamente saltar para bem perto de uma personagem para observar uma sutil hesitação em sua face (MACHADO, 2007, p. 26).

Vale salientarmos que uma interessante lógica de representação se faz atinar na relação estabelecida entre Dom Casmurro e o espectador. Trata-se da mani- 
pulação dos ângulos de filmagem ${ }^{16}$, constatada na verticalidade da câmera objetiva (Figura 5). Há dois tipos de planos correlativos à angulação da cena: o plongée e o contra-plongée $e^{17}$. É perceptivel que, quando Dom Casmurro fala diretamente à câmera (fazendo desta seu espectador-ouvinte), mas sem inserir-se na cena representada, o ângulo de filmagem preferencial é o contra-plongée (de baixo para cima). Já nos momentos em que fala "de dentro" das cenas, às vezes, próximo aos personagens, a câmera tende a assumir a posição normal, isto é, horizontal, dispondo-se à mesma altura de seus olhos.

\section{Figura 5 - Posicionamentos do olhar da câmera}
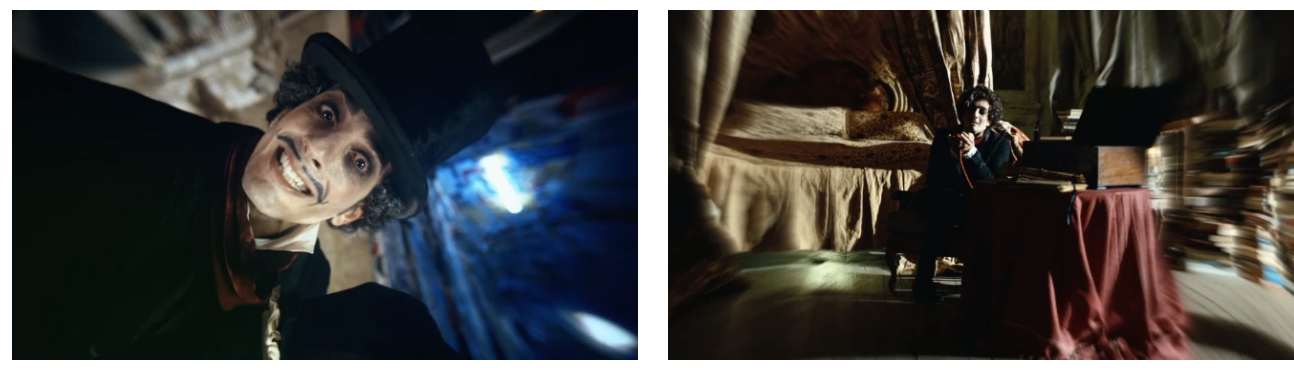

Fonte: DVD Microssérie Capitu (2008).

Tal relacionamento perspectivo entre Dom Casmurro e o espectador produz um efeito de sentido paradoxal. Uma vez visto de baixo para cima, cuja figura praticamente preenche todo o enquadramento, Dom Casmurro se mostra como entidade possuidora das rédeas da narrativa, e o intuito é significar que os fatos narrados seguem o compasso de seu ponto de vista. É uma implícita tentativa de manipulação do olhar: feito uma marionete, o espectador se vê atado a cordéis invisiveis, que são as reminiscências dessa personagem casmurra, e movido, do alto, por meio do seu ponto de vista "superior", originador da narrativa. A oposição aparece, todavia, no instante em que o mesmo personagem fala do interior da ambiência de suas memórias. O olhar da câmera, nessa circunstância, nivela-se à mesma elevação dos olhos do protagonista. Isso acaba por mimetizar a autonomia desse observador em ponderar a narrativa a partir de sua observância autônoma dos fatos e comportamentos, tendo em conta a parcialidade do ponto de vista que palmilha a história, ou seja, o olhar unilateral de Dom Casmurro. Assim, o espectador tem a oportunidade de cortar os cordões e movimentar-se por conta própria.

Mais um efeito de sentido é produzido no episódio "Na varanda" (Figura 6), que mostra Bentinho e Capitu deitados, a florear conversações e confidências:

16 De acordo com a teoria do cinema, o ângulo de filmagem corresponde à perspectiva pela qual "o sujeito é filmado. A filmagem pode ser frontal em relação ao eixo horizontal e vertical do sujeito filmado; ou o ângulo pode ser considerado de cima para baixo ou da direita para a esquerda" (COSTA, 2003, p. 181).

17 Também chamada de plano picado ou câmera alta, a posição plongée (do francês, "mergulho") filma o sujeito de cima para baixo, situando a objetiva da câmera acima do nível convencional dos olhos. O efeito produzido por essa tomada de filmagem "tem tendência para tornar o indivíduo ainda mais pequeno, esmagando-o moralmente ao colocá-lo no nível do solo, fazendo dele um objeto levado por uma espécie de determinismo impossível de ultrapassar, um brinquedo do destino" (MARTIN, 2005, p. 51). Por sua vez, a posição contra-plongée ("contramergulho", no francês) tende a mostrar o objeto de baixo para cima, e localiza a câmera abaixo do nível dos olhos. É conhecida como plano contrapicado ou câmera baixa. Seu uso cria "uma impressão de superioridade, de exaltação e de triunfo, porque engrandece os indivíduos e tende a magnificá-los, recortando-os no céu até os envolver numa auréola de neblina" (MARTIN, 2005, p. 51). Por outro lado, como nos informam Jullier e Marie (2009, p. 26), nem sempre será automática a correlação entre o tipo de ângulo e seu sentido culturalizado, pois "uma câmera baixa obrigatoriamente não magnifica, assim como uma câmera alta necessariamente não esmaga". O significado dependerá, também, de implicações contextuais da obra audiovisual e intencionais de seu produtor. 
ela the tecendo elogios aos cabelos, ele elogiando-a de volta, ela dizendo que sonhara com ele na véspera, que os anjos lhes perguntando os nomes "a fim de os dar a outros anjos que acabavam de nascer” (ASSIS, 1997, p. 34).

Figura 6 - Posicionamentos do olhar da câmera
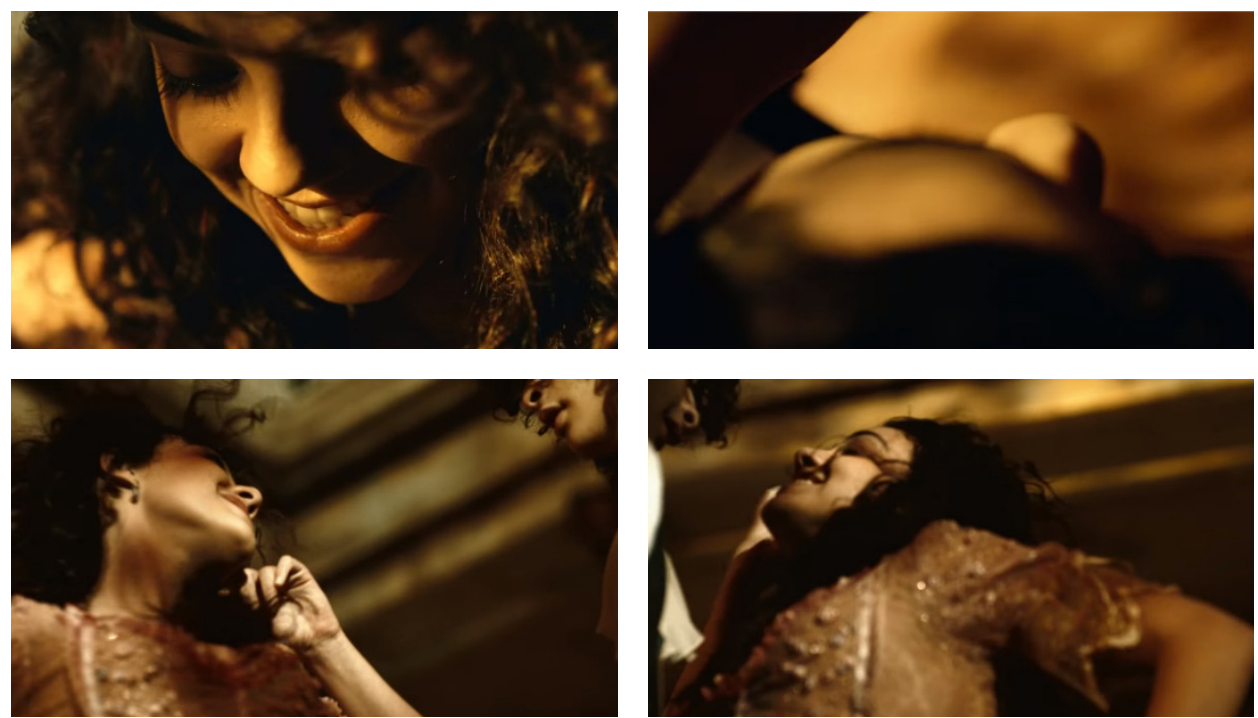

Fonte: DVD Microssérie Capitu (2008).

Nessa sequência, a câmera se posiciona bem próximo às personagens, e os planos destacam os rostos de Capitu e Bentinho e a troca de afagos nos cabelos. Claramente, esse olhar invisivel e observador aí colocado quer que o espectador se achegue à atmosfera de afeto que envolve os adolescentes, dividindo com ele, bem de perto, a cumplicidade do momento nas suas minúcias, isso porque, no encontro, Bentinho toma consciência do tipo de relação que tem com Capitu. Em verdade, o "olho" da câmera, literalmente, deita-se junto ao casal e compartilha do enlevo e enamoramento que emana dos diálogos e gestos.

Quando ambos se põem de pé, a câmera permanece em posição inferior e os visualiza em contra-plongée, ocasião em que Capitu segreda a Bentinho o sonho angélico que tivera. Imageticamente, o olhar posicionado abaixo das personagens insinua a concretização do sonho de Capitu: posto que a câmera permanece ao nível do chão (portanto, no plano terrestre), a distância, assim estabelecida, sugere, de fato, a elevação dos adolescentes ao plano celeste, local perene onde reina a pureza e a inocência casta dos anjos, fulgurações transmitidas pelas descobertas amorosas que fazem os jovens nas cenas em questão. Isso se confirma pela luz de ouro que incide sobre os personagens, transmitindo também a ideia de perpétuo sentimento que os une, sabendo-se que o "amarelo é a cor da eternidade, como o ouro é o metal da eternidade" (CHEVALIER; GHEERBRANT, 2015, p. 40).

Em Capitu, também o olhar da câmera, como figuração de um observador oculto, é possuidor de sagaz capacidade de penetrar lugares e revelar pormenores dos mais clandestinos, aspecto que muito se avizinha à noção de ubiquidade. Então, além da destreza em movimentar-se livremente, esse observador se nota- 
biliza por “[...] também ser uma espécie de onipotência, capaz de encarnar um pássaro ou um computador, voar como uma ave ou colocar-se em ângulos impossiveis, como se fosse uma expressão da divindade" (MACHADO, 2007, p. 28).

Como ilustrações a esse conceito, podemos citar o momento em que José Dias compara Bento Santiago e Capitu, já adultos e casados, a aves criadas nos vãos de telhado (Figura 7). Então, a objetiva da câmera visualiza Dom Casmurro com um par de pombinhas nas mãos, gesticulando soltá-lo para alçar voo. Em seguida, há um corte de cena, e os planos seguintes se transmutam na perspectiva das aves planando no céu, cujo olhar observa, do alto, as ruas e os prédios da cidade do Rio de Janeiro, bem como a estátua do Cristo Redentor.

Figura 7 - Ubiquidade da câmera encarnada na visão de pássaros
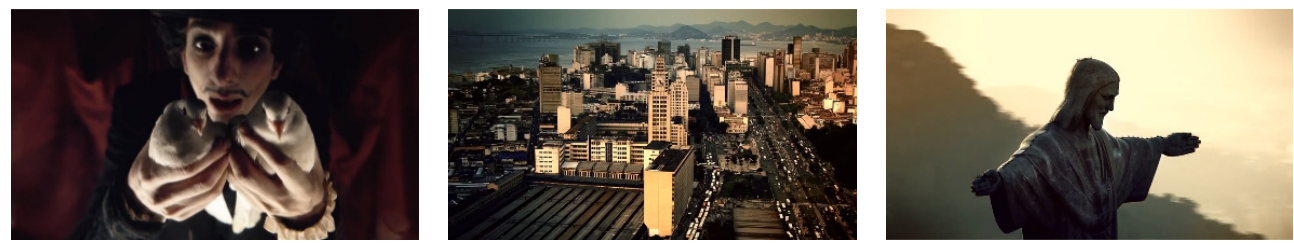

Fonte: DVD Microssérie Capitu (2008).

As imagens aéreas são pontuadas pela faixa musical Desabafo, interpretada pelo rapper Marcelo D2 e pela cantora Cláudya, canção que mescla jazz e hip hop. A música traz como mensagem o desabafo de alguém que possui uma opinião crítica acerca da realidade e que sente necessidade de externá-la livremente, conforme é possível se depreender do refrão: "Deixa, deixa, deixa eu dizer o que penso desta vida/ Preciso demais desabafar!”. Dessa forma, o tom libertário apregoado pela trilha sonora se alinha ao voo das aves, que, em parceria, simbolizam a leveza proporcionada pela liberdade de poder se expressar abertamente, ao mesmo tempo que torna o espectador participante desse sentimento.

Outra situação em que a ubiquidade aplicada à câmera ganha corpo diz respeito à simulação de Dom Casmurro em datilografar trechos de seu romance sobre a lente da câmera, transubstanciando a tela em páginas de livro (Figura 8).

Figura 8 - Ubiquidade da câmera como páginas de livro

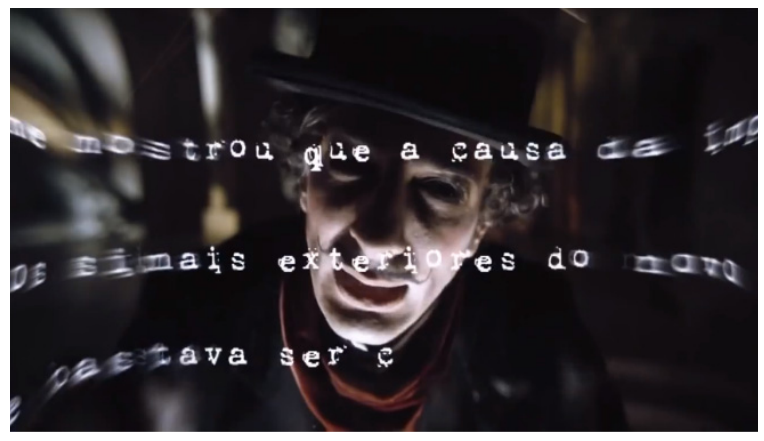

Fonte: DVD Microssérie Capitu (2008).

O efeito metafórico obtido por essa técnica aponta para o fato de que Dom Casmurro tenta, literalmente, escrever nos olhos do espectador-leitor sua visão 
da trama, cujo ponto de vista referente às memórias segue tão somente o ritmo descompassado das batidas de seus dedos nas teclas da máquina de escrever imaginária. Deseja, portanto, registrar a sua versão da história, presumindo que a consciência desse observador se apresenta virgem de qualquer pré-julgamento, igualmente às páginas brancas de um livro que recebe a impressão gráfica das letras para constituir uma narrativa. Não obstante, as informações que anota nas "retinas de papel" do olhar que lhe encara já se encontram com os borrões de seu frágil estado psicológico, fazendo-se inevitável a desconfiança quanto à nitidez e veracidade de suas palavras.

\section{E bem, e o resto?}

Ao cabo dessas explanações, consideramos ser nítida a constatação de que as estratégias e os mecanismos que arquitetam a ficção audiovisual, aqui abordados pela análise da microssérie Capitu, constituem um conjunto mais amplo de códigos, dada a diversidade do texto televisivo. Por esse aspecto, entende-se que o dispositivo aqui analisado - exploração do "olho" da câmera -, dentre tantos outros, é rastro evidente da entidade enunciadora na narrativa audiovisual analisada. Consideramos, ainda, que falar em "narrador" ou instância narradora na teleficção, como nas demais modalidades narrativas que manipulam a imagem-som em seus dizeres, traz no seu bojo o entendimento de que os procedimentos de narração correspondem a uma matriz organizadora e articuladora da história, que agencia e ancora dispositivos plurais de expressão, ao mesmo tempo que lança luz à especificidade do ato narrativo na audiovisão.

Pela releitura contemporânea do narrador literário feita por Luiz Fernando Carvalho na microssérie Capitu, tornam-se visiveis, também, as novas posturas de adaptação do texto ficcional para o cinema e a TV. A estética particular do diretor consegue comportar a narrativa audiovisual em formato de microssérie, por meio da elaboração de uma nova linguagem, experienciando novos modos de narrar.

Dessa forma, tendo em vista a construção e as opções do diretor para narrar a trajetória de Dom Casmurro, é inegável constatar que a microssérie, como adaptação que é, sugere criativamente ao espectador novas possibilidades de se relacionar com uma história já consagrada literariamente, acrescentando também novos caminhos para sua interpretação e até questionando leituras consolidadas. E, sem dúvida, entre as estratégias usadas, a movimentação da câmera é também um recurso enunciativo rico, que tende a provocar, no espectador, o desejo de ler e interpretar seus movimentos, dado que seus deslocamentos, certamente, não são esvaziados de sentido. E, assim, se for da vontade do espectador, assistir a uma microssérie ou a um filme, nesse sentido, é um processo bem pessoal de descoberta, de aprendizagem e de construção de sentidos e, sobretudo, de recriação de uma narrativa literária.

\section{OF THE LIPS THAT NARRATE TO THE INVISIBLE EYE: NARRATIVE STRATEGIES IN CAPITU}

Abstract: This article investigates the audiovisual exhibition strategies in order to understand how a narration happens in the microseries Capitu (2008), directed by Luiz Fernando Carvalho. There are also the contributions of cinematographic narratology, about the existence of a narrative instance in the 
cinema, in tracing of the enunciative expedients responsible for the narrative activity in the Carvalhian work. It stands out the manipulation of the camera as one of the narrative traits that, articulated and attuned to other sources, collaborates for the specificity of narration in the microseries.

Keywords: Adaptation. Audiovisual aesthetics. Serial fiction. Narrative instance. Microserie Capitu.

\section{REFERÊNCIAS}

ADORNO, T. W. Posição do narrador contemporâneo. In: ADORNO, T. W. Notas de literatura I. São Paulo: Duas Cidades: Editora 34, 2003.

ASSIS, M. de. Dom Casmurro. São Paulo: Globo, 1997.

AUMONT, J.; MARIE, M. Dicionário teórico e crítico de cinema. Tradução Eloisa Araújo Ribeiro. Campinas: Papirus, 2003.

BAUDELAIRE, C. O pintor da vida moderna. In: BAUDELAIRE, C. Poesia e prosa. Rio de Janeiro: Nova Aguilar, 2006.

BENJAMIN, W. O narrador. Considerações sobre a obra de Nikolai Lesbov. In: BENJAMIN, W. Obras escolhidas: magia e técnica, arte e política. 3. ed. São Paulo: Brasiliense, 1987. v. 1.

BENJAMIN, W. O flâneur. In: BENJAMIN, W. Obras escolhidas: Charles Baudelaire um lírico no auge do capitalismo. 3. ed. São Paulo: Brasiliense, 2000. v. 3.

BETTON, G. Estética do cinema. São Paulo: Martins Fontes, 1987.

BORDWELL, D. La narración em el cine de ficción. Tradução Pilar Vásquez Mota. Barcelona: Buenos Aires: Paidós, 1996.

BULHÕES, M. A questão do narrador na ficção midiática. Revista Alceu, Rio de Janeiro, v. 9, n. 18, p. 48-55, jan./jun. 2009. Disponivel em: http://revistaalceuacervo.com.puc-rio.br/media/Alceu\%2018_artigo\%203\%20(pp48\%20a\%2055). pdf. Acesso em: 14 mar. 2019.

CAPITU. Direção: Luiz Fernando Carvalho. Escrito por Euclydes Marinho. Colaboração: Daniel Piza, Edna Palatnik e Luís Alberto de Abreu. Texto final: Luiz Fernando Carvalho. Produção de arte: Isabela Sá. Figurino: Beth Pilipecki. Direção de fotografia: Adrian Teijido. Edição: Marcio Hashimoto Soares. Música: Tim Rescala. Intérpretes: Michel Melamed, Maria Fernanda Cândido, Eliane Giardini, Letícia Persiles, Cesar Candadeiro, Pierre Baitelli, Paulo José. Rio de Janeiro: TV Globo, Projeto Quadrante, 2008-2009. 2 DVDs (118 minutos e 112 minutos). Incluindo: Fragmentos (making off, Ruminações (palestras) e Papel Avulso (cena Marcolini); full screen; son.; color. Português com legendas em inglês, francês e espanhol. Microssérie.

CHEVALIER, J.; GHEERBRANT, A. Dicionário de simbolos: mitos, sonhos, costumes, gestos, formas, figuras, cores, números. 27. ed. Tradução Vera da Costa e Silva. Rio de Janeiro: José Olympio, 2015.

COSTA, A. Compreender o cinema. Tradução Nilson Moulin Louzada. 3. ed. São Paulo: Globo, 2003.

FIORIN, J. L. Interdiscursividade e intertextualidade. In: BRAIT, B. (org.). Bakhtin: outros conceitos-chave. São Paulo: Contexto, 2006. 
GARDIES, R. (org.). Compreender o cinema e as imagens. Lisboa: Edições Texto \& Grafia, 2006.

GAUDREAULT, A.; JOST, F. A narrativa cinematográfica. Tradução Adalberto Müller. Brasília: Editora UnB, 2009.

GENETTE, G. Discurso da narrativa: ensaio de método. Lisboa: Editora Arcádia, 1978.

JULLIER, L.; MARIE, M. Lendo as imagens do cinema. Tradução Magda Lopes. São Paulo: Editora Senac São Paulo, 2009.

MACHADO, A. O sujeito na tela: modos de enunciação no cinema e no ciberespaço. São Paulo: Paulus, 2007. (Coleção Comunicação).

MARTIN, M. A linguagem cinematográfica. Tradução Lauro António e Maria Eduarda Colares. Lisboa: Dinalivro, 2005.

METZ, C. La enunciación impersonal o la perspectiva del film. Tradução Elda Rojas Aldunate. México: Universida Veracruzana, 1993. (Investigaciones linguístico literarias).

POUILlON, J. O tempo no romance. Tradução Heloysa de Lima Dantas. São Paulo: Cultrix/Edusp, 1974.SANTIAGO, S. Nas malhas da letra: ensaios. Rio de Janeiro: Rocco, 2002.

SILVA, K. C. da. A imagem da palavra e a palavra da imagem: urdiduras do olhar em Lavoura arcaica. 2011. 165 f. Tese (Doutorado em Ciência da Literatura) - Universidade Federal do Rio de Janeiro, Rio de Janeiro, 2011.

STANZEL, F. Formas tipicas do romance. Göttingen: Vandenhoeck und Ruprecht, 1971.

TACCA, O. As vozes do romance. 2. ed. Coimbra: Livraria Almedina: 1983.

TODOROV, T. As categorias da narrativa literária. In: BARTHES, R. Análise estrutural da narrativa. Tradução Maria Zélia Barbosa Pinto. 7. ed. Petrópolis, RJ: Vozes, 2011. 